\title{
Bay anchovy Anchoa mitchilli production and consumption in mid-Chesapeake Bay based on a bioenergetics model and acoustic measures of fish abundance
}

\author{
Jiangang Luo, Stephen B. Brandt
}

Chesapeake Biological Laboratory, Center for Environmental and Estuarine Studies, Solomons, Maryland 20688-0038, USA

\begin{abstract}
A growth model of bay anchovy Anchoa mitchilli was developed based on weight and temperature-specific physiological data taken from laboratory and field experiments. The model was adjusted for Chesapeake Bay (USA) conditions to estimate bay anchovy population production and consumption as a function of bay anchovy hatch date, annual mortality, and acoustic measures of fish abundance. Spatially explicit models of bay anchovy consumption were developed to demonstrate how changes in spatial patterning and absolute scaling of the biological and physical environment might affect prey consumption in May and July. In model simulations, bay anchovy grew 3 to $6 \% \mathrm{~d}^{-1}$ during summer and fall, and young-of-the-year ( $Y O Y$ ) bay anchovy biomass peaked in November $\left(16270 \mathrm{~kg} \mathrm{~km}^{-2}\right)$. Weight-specific consumption rate of juvenile bay anchovy was about $60 \% \mathrm{~d}^{-1} \mathrm{during}$ summer, and population consumption peaked in September $\left(3350 \mathrm{~kg} \mathrm{~km} \mathrm{kd}^{-2} \mathrm{~d}^{-1}\right)$. Population production rate of YOY also peaked in September at $290 \mathrm{~kg} \mathrm{~km}^{-2} \mathrm{~d}^{-1}$, and annual production was $30770 \mathrm{~kg}$ $\mathrm{km}^{-2}$ If all mortality was due to predation, bay anchovy could provide $133 \mathrm{~kg}$ food $\mathrm{km}^{-2} \mathrm{~d}^{-1}$ for piscivores in November, which could support the maximum daily consumption of 13300 age-2 striped bass Morone saxatilis per $\mathrm{km}^{2}$. The average trophic efficiency of bay anchovy was $10.7 \%$ with a large seasonal variation (0 to $18 \%$ ). Sensitivity analyses identified that weight and temperature-specific consumption and respiration parameters were most sensitive in model simulations of fish growth. Compared with the estimated zooplankton production, the average bay anchovy consumption only accounted for a small portion of daily zooplankton production. But our spatially-explicit model indicated that local depletions of zooplankton were possible due to spatial patchiness of predator and habitat heterogeneity, particularly in July.
\end{abstract}

\section{INTRODUCTION}

The bay anchovy Anchoa mitchilli is the most abundant pelagic prey species and a critical trophic link in the Chesapeake Bay, USA, system (Hildebrand \& Schroeder 1928, Hildebrand 1943, 1963, Hollis 1952, Merriner 1975, Chao \& Musick 1977, Homer \& Boynton 1978, Safina \& Burger 1989, Baird \& Ulanowicz 1989). Bay anchovy are the primary prey of the top 3 piscivores in the Bay and may consume as much as 70 to $90 \%$ of the total zooplankton consumed by all planktivorous fishes (Baird \& Ulanowicz 1989).

The declining water quality, loss of shallow water habitats, and declines in valuable fish populations have alerted agencies and ecologists throughout the
Chesapeake Bay region to the need for ecosystemlevel modeling to define the food-web linkages between water quality issues and fisheries production and management (Carpenter et al. 1985, 1987, Scavia et al. 1986, Carpenter \& Kitchell 1988, Verity 1988, Lee \& Jones 1991, Hunter \& Price 1992, Power 1992, Strong 1992). An ecosystem model is usually constructed with multiple trophic levels consisting of many components. The accuracy of estimating the state of components and flows between trophic levels is important to system-level modeling. The bay anchovy is believed to be the major linkage between secondary zooplankton production and piscivore production in Chesapeake Bay. Therefore, quantifying bay anchovy production and consumption of zooplankton is crucial for system- 
level models. Thus, our primary focus in this paper is to develop an accurate and robust model of bay anchovy growth and consumption.

Bioenergetics models have been used widely to evaluate fish growth and consumption. The basic model developed by Kitchell et al. (1977) and Hewett \& Johnson $(1987,1992)$ is one of the most frequently employed bioenergetics models in fish ecology. The applications include assessing the effects of global warming on fish production (Hill \& Magnuson 1990); predicting peak host mortality in sea lamprey Petromyzon marinus (Kitchell \& Breck 1980); evaluating planktivore control of zooplankton biomass in the Great Lakes (Hewett \& Stewart 1989); predicting stocking success of esocids under various thermal regimes (Bevelheimer et al. 1985); determining the predatory demands of salmonids in relation to prey abundances (Brandt et al. 1991a, Stewart \& Ibarra 1991) and evaluating growth responses of fishes to changing environmental conditions, prey abundances, or through ontogeny (Hewett 1989). Also, sensitivity analyses (Kitchell et al. 1977, Stewart et al. 1983, Bartell et al. 1986) and model validation studies (Rice \& Cochran 1984, Beauchamp et al. 1989) show that bioenergetics models generally provide accurate and relatively robust estimates of fish growth and consumption.

In this paper, we develop the basic bioenergetics model for an individual bay anchovy and then, using quantitative acoustic measurements of bay anchovy abundances, apply the model at the population level to the mid-Chesapeake Bay region to quantify the seasonal patterns of bay anchovy production and predation on zooplankton.

\section{MATERIALS AND METHODS}

Model development. We have adopted the basic bioenergetics modeling framework of Kitchell et al. (1977) and Hewett \& Johnson (1987, 1992) for estimating growth and consumption of bay anchovy in Chesapeake Bay. The model balances the flow of energy through an individual fish among the pathways of consumption (flow in), growth (somatic and reproduction), and energy loss (respiration, specific dynamic action, egestion, and excretion). Biomass (weight) is converted to energy by using the caloric density of prey and predators. Specific growth rate $(\mathrm{d} B / B \mathrm{~d} t)$ is defined by the equation

$$
\frac{\mathrm{d} B}{B \mathrm{~d} t}=C-(R+F+U)
$$

where $B=$ weight of fish; $t=$ time $_{i} C=$ consumption; $R=$ respiration $F=$ egestion; and $U=$ excretion. The model calculates the terms of this budget on a daily basis, providing estimates of individual growth rates, consumption, or, if the initial population size and mortality are supplied, population production over the simulation period. Rates of consumption and respiration are nonlinear functions of fish weight and water temperature. Estimates for parameters of those functions were taken from published literature or reports on the bay anchovy. The parameter symbols and values are summarized in Table 1. Detailed descriptions of model parameterization are presented below.

Consumption: Consumption $(C)$ is defined as the rate of feeding, and is modeled as a function of fish weight, water temperature, and food availability

$$
C=a_{\mathrm{c}} W^{b_{\mathrm{c}}} f(T) P
$$

where $a_{c}=$ maximum consumption rate of a $1 \mathrm{~g}$ bay anchovy at the optimal temperature for consumption [ $g$ prey ( $g$ body $w t)^{-1} d^{-1}$ ]; $b_{c}=$ exponent for the weight dependence of the consumption; $W=$ wet weight of bay anchovy in grams; $f(T)=$ a proportional adjustment ( 0 to 1.0 ) of consumption defined by a temperaturedependent function in Kitchell et al. (1977); and $P=$ proportion of maximum consumption realized. The maximum consumption at the optimal temperature is defined as $C_{\max }=a_{c} W^{b_{c}}$.

The preferred temperatures for juvenile and adult bay anchovy have been estimated ranging from 20 to $30^{\circ} \mathrm{C}$, and estimates of the maximum tolerance temperatures range from 27 to $40^{\circ} \mathrm{C}$ (Houde \& Zastrow 1991, and references therein). We chose $27^{\circ} \mathrm{C}$ as the optimal temperature $\left(T_{0}\right)$ and $33^{\circ} \mathrm{C}$ as the maximum temperature $\left(T_{m}\right)$ for consumption based on laboratory experiments of Vazquez (1989). The slope of temperature dependence of consumption (2.22) was calculated from the temperature dependent evacuation rates, and the temperature range was 19 to $27^{\circ} \mathrm{C}$ (Vazquez 1989).

The weight-dependent function for consumption was derived from laboratory (Vazquez 1989) and field (Klebasko 1991) studies on bay anchovy. The sizes of fish in both studies were similar $(0.4$ to $2.5 \mathrm{~g}$ in laboratory, 0.2 to $2.5 \mathrm{~g}$ in field). Daily consumptions in the field were calculated by applying Elliott \& Persson's (1978) model to weight-specific stomach contents ( $\mathrm{g} \mathrm{g}^{-1}$, wet wt) of bay anchovy collected during two $24 \mathrm{~h}$ periods (23-24 July and 15-16 August 1990; Klebasko 1991). Water temperatures during July and August were the same $\left(27^{\circ} \mathrm{C}\right.$ K Klebasko 1991), therefore the 2 samples were combined. We assumed that the rate of gastric evacuation $(r)$ was exponential and temperature-dependent (Vazquez 1989), and that the fish feeding rates could be different throughout the day. Therefore, the amount of food consumed in a time period of $t h$ is defined by

$$
C_{t}=\frac{\left(S_{t}-S_{0} \mathrm{e}^{-r t}\right) r t}{1-\mathrm{e}^{-s t}}
$$


Table 1. Symbols and parameter values used in model equations of bay anchovy growth and consumption

\begin{tabular}{|c|c|c|}
\hline \multicolumn{2}{|r|}{ Parameter description } & Parameter value \\
\hline \multicolumn{3}{|c|}{ Consumption } \\
\hline$a_{c}$ & Intercept for maximum consumption $\left(\mathrm{g} \mathrm{g}^{-1} \mathrm{~d}^{-1}\right)$ & 0.41 \\
\hline$b_{c}$ & Exponent for maximum consumption & -0.33 \\
\hline$Q$ & Slope for temperature dependence of consumption & 2.22 \\
\hline$T_{o}$ & Optimum temperature for consumption & $27^{\circ} \mathrm{C}$ \\
\hline$T_{\mathrm{m}}$ & Maximum temperature for consumption & $33^{\circ} \mathrm{C}$ \\
\hline \multicolumn{3}{|c|}{ Respiration } \\
\hline$a_{r}$ & Intercept for maximum standard respiration $\left(\mathrm{g} \mathrm{O}_{2} \mathrm{~g}^{-1} \mathrm{~d}^{-1}\right)$ & 0.0115 \\
\hline$b_{r}$ & Exponent for maximum standard respiration & -0.346 \\
\hline$Q$ & Slope for temperature dependence of standard respiration & 2.25 \\
\hline$T_{0}$ & Optimum temperature for standard respiration & $30^{\circ} \mathrm{C}$ \\
\hline$T_{\mathrm{m}}$ & Maximum temperature for standard respiration & $36^{\circ} \mathrm{C}$ \\
\hline$S$ & Specific dynamic action coefficient & 0.10 \\
\hline A & Activity parameter & 2.0 \\
\hline \multicolumn{3}{|c|}{ Egestion and excretion } \\
\hline & Intercept for temperature dependence of egestion & 0.77 \\
\hline$\beta$ & Exponent for temperature dependence of egestion & -0.40 \\
\hline$a_{u}$ & Proportion of assimilated food excreted & 0.15 \\
\hline
\end{tabular}

perature of $27^{\circ} \mathrm{C}$ was 2.5 , as measured by Vazquez (1989) in the laboratory. Maximum daily consumption was plotted as a function of fish weight and the parameters $\left(a_{c}, b_{c}\right)$ were estimated by a log-linear regression:

$$
\begin{aligned}
& \ln \left(C_{\max }\right)=\ln \left(a_{c}\right)+b_{c} \ln (W) \\
& \mathrm{r}^{2}=0.73, \mathrm{p}>0.003, a_{\mathrm{c}}=0.41, b_{\mathrm{c}}= \\
& -0.33
\end{aligned}
$$

Respiration: Respiration rate was modeled as an allometric function of body weight, water temperature, fish activity level, and specific dynamic action:

$$
R=a_{\mathrm{r}} W^{b_{\mathrm{r}}} f(T) A+S(C-F)
$$

where $a_{\mathrm{r}}=$ standard respiration rate of a $1 \mathrm{~g}$ bay anchovy at the optimal temperature for respiration $\left[\mathrm{g} \mathrm{O}_{2}\right.$ (g body $w t)^{-1} \mathrm{~d}^{-1}$ ], and $b_{r}=$ exponent where $C_{t}=$ consumption of food by a fish over a time interval $t_{i} S_{t}=$ mean weight-specific stomach content at the end of the interval; $S_{0}=$ mean weight-specific stomach content at the beginning of the interval; and $r=$ instantaneous evacuation rate. If $m$ samples are taken over $24 \mathrm{~h}$, and $t_{i}\left(i=1, \ldots, m_{;} m\right.$ is number of samples in $24 \mathrm{~h}$ ) is used to indicate the time when each sample was taken, then daily consumption $(C)$ is estimated by summing $C_{t_{i}}$ over the $24 \mathrm{~h}$ period (Elliott \& Persson 1978):

$$
C=\sum_{i=1}^{m} C_{t_{i}} .
$$

To estimate maximum daily consumption $\left(C_{\text {max }}\right)$, we added a standard error to the mean weight-specific stomach content before applying Eqs. (3) \& (4) (Table 2). The instantaneous evacuation rate $(r)$ at a water tem- for the weight dependence of respiration; $W=$ wet weight of bay anchovy; $f(T)=$ a temperature-dependent proportional adjustment of respiration rate similar to that in Eq. (2); $A$ = activity parameter to specify respiration rates above standard level; $S=$ specific dynamic action coefficient, defined as the metabolic cost of digestion, absorption and deposition of consumed energy; $F=$ egestion as defined in Eq. (7); and $C=$ realized consumption as defined in Eq. (2).

There are few reliable data for the optimal and maximum temperature of respiration for bay anchovy. After reviewing Houde \& Zastrow (1991), we chose 30 and $36^{\circ} \mathrm{C}$ as the optimal and maximum temperatures for respiration, respectively. The slope for temperature dependence of respiration $(Q=2.25)$ was taken from Vazquez

\begin{tabular}{|c|c|c|c|c|c|c|c|c|}
\hline \multirow{2}{*}{$\begin{array}{l}\text { Wet fish } \\
\text { weight (g) }\end{array}$} & \multicolumn{6}{|c|}{ Time of sample $(\mathrm{h})$} & \multirow{2}{*}{$\begin{array}{l}\text { Calculated } \\
C_{\max }\end{array}$} & \multirow{2}{*}{$\begin{array}{l}\text { Predicted } \\
\qquad C_{\max }\end{array}$} \\
\hline & $03: 00$ & $07: 00$ & $11: 00$ & $15: 00$ & $19: 00$ & $23: 00$ & & \\
\hline 0.18 & 0.0048 & 0.0024 & 0.0140 & 0.0256 & 0.0078 & 0.0049 & 0.592 & 0.722 \\
\hline 0.25 & 0.0014 & 0.0026 & 0.0176 & 0.0326 & 0.0190 & 0.0051 & 0.746 & 0.648 \\
\hline 0.35 & 0.0022 & 0.0027 & 0.0149 & 0.0348 & 0.0165 & 0.0054 & 0.733 & 0.580 \\
\hline 0.55 & 0.0020 & 0.0028 & 0.0101 & 0.0173 & 0.0163 & 0.0058 & 0.506 & 0.499 \\
\hline 0.85 & 0.0005 & 0.0031 & 0.0057 & 0.0158 & 0.0072 & 0.0026 & 0.330 & 0.433 \\
\hline 1.15 & 0.0016 & 0.0027 & 0.0036 & 0.0112 & 0.0114 & 0.0050 & 0.321 & 0.392 \\
\hline 1.50 & 0.0017 & 0.0172 & 0.0027 & 0.0100 & 0.0037 & 0.0059 & 0.371 & 0.359 \\
\hline 1.80 & 0.0065 & 0.0012 & 0.0004 & 0.0151 & 0.0105 & 0.0060 & 0.401 & 0.338 \\
\hline 2.10 & 0.0014 & 0.0031 & 0.0032 & 0.0122 & 0.0110 & 0.0099 & 0.323 & 0.321 \\
\hline
\end{tabular}
(1989) and the temperature range was 19 to $27^{\circ} \mathrm{C}$. The oxygen uptakes by bay anchovy in laboratory experi-

Table 2. Anchoa mitchilli. Bay anchovy $C_{\max }$ calculation at $27^{\circ} \mathrm{C}$ the values in the table are mean weight-specific stomach contents plus 1 SE ( $\mathrm{g} \mathrm{g}^{-1}$ wet wt). Data from Klebasko (1991) 
ments (Vazquez 1989) were recalculated to estimate the regression parameters, $a_{\mathrm{r}}=0.01146$ and $b_{\mathrm{r}}=-0.3455$ $\left(\mathrm{r}^{2}=0.96, \mathrm{p}<0.001\right)$. The activity parameter or the 'Winberg multiplier' $(A)$ was set at 2.0 and the specific dynamic action (S) was taken as a constant $10 \%$ of the assimilated food (Kitchell et al. 1977, Hewett \& Johnson 1987).

Egestion and excretion: Egestion was modeled as a function of consumption and water temperature:

$$
F=C \alpha T^{\beta}
$$

where $C=$ consumption $\left(\mathrm{g} \mathrm{g}^{-1} \mathrm{~d}^{-1}\right) ; \alpha=$ proportion of consumption egested when temperature is $1{ }^{\circ} \mathrm{C} ; \beta=$ exponent for the temperature dependence of egestion; and $T=$ water temperature. The values of $\alpha$ and $\beta$ were estimated from Vazquez's (1989) laboratory data on energy budgets of bay anchovy by a log-linear regression. Excretion was modeled as a constant fraction $(15 \%)$ of assimilated food, independent of size, temperature, and consumption rate.

The bay anchovy is a multiple spawning species and all individuals are mature by the second summer (approximately age 1). Luo \& Musick (1991) and Zastrow et al. (1991) reported that bay anchovy spawned almost daily throughout the summer, and that average spawning output was about $3 \%$ of body energy. Therefore, for accurately estimating the consumption of mature bay anchovy, the spawning output was modeled as an equivalent of an excretion of $3 \%$ of body energy per day during the spawning period.

Implementation of the model. Model simulations were run using a computer program developed by Hewett \& Johnson $(1987,1989,1992)$, which is available from the University of Wisconsin Sea Grant Institute (1800 University Avenue, Madison, WI 53705, USA). In simulations, we solved weight-specific growth rates and weight-specific consumption rates as a function of time based on species-specific physiological parameters described above as well as site-specific data of ambient water temperatures (30 yr arithmetic average $e_{i}$ Ritchie \& Genys 1975), caloric densities of bay anchovy $(1000 \mathrm{cal}$ $\mathrm{g}^{-1}$ wet $\mathrm{wt}$, measured from field collected samples) and its prey $\left(610 \mathrm{cal} \mathrm{g}^{-1}\right.$ wet $\mathrm{wt}$, averaged for all prey; Hewett \& Johnson 1989), and initial and end weights of bay anchovy (Houde et al. 1989). Since the bay anchovy exhibits a protracted spawning season (Hildebrand 1943, 1963, Luo \& Musick 1991, Zastrow et al. 1991), we divided the young-of-the-year (YOY) bay anchovy population into 8 cohorts according to their hatching dates (15 d interval) and ran the model by cohort. To accomplish population level simulation, bay anchovy hatchdate frequency distribution (Zastrow et al. 1991) was used to initialize the relative population size of each cohort and a $95 \%$ annual mortality was applied to the population (Newberger 1989, Luo 1991). Simulations were run with a starting age of $40 \mathrm{~d}$ after hatch and initial weight of $0.05 \mathrm{~g}$ for all cohorts, and end weights of YOY cohorts ranging from 0.6 to $2.1 \mathrm{~g}$ (Houde et al. 1989). The age 1+ bay anchovy were modeled from May 15 to December 1 as one cohort to estimate their consumption during this period. Bay anchovy younger than $40 \mathrm{~d}$ were not included in our simulations because our main objective was to estimate consumption, not growth, and the model parameters were estimated from juvenile and adult bay anchovy. Bay anchovy older than $1.5 \mathrm{yr}$ were also not included in our simulations because they presented less than $1 \%$ of total population (Newberger 1989).

Sensitivity analysis. A single parameter analysis of sensitivity was performed to evaluate the relative importance of input parameters for yearly growth output and yearly consumption output. The model sensitivity for each parameter is defined as (Kitchell et al. 1977)

$$
S_{k}=\frac{V_{k} \Delta Y}{Y \Delta V_{k}}
$$

where $S_{k}=$ sensitivity for parameter $k_{i} V_{k}=$ the nominal value of parameter $k_{i} \Delta V_{k}=$ input deviation of parameter $k_{i} Y=$ model output of the variable under testing (i.e. yearly growth or yearly consumption); and $\Delta Y=$ change in the model output as the result of the change of the parameter $k$. In sensitivity analysis simulations, we varied each parameter separately by $\pm 10 \%\left(\Delta V_{k}=V_{k} / 10\right)$ except for $T_{\mathrm{o}}$ and $T_{\mathrm{m}}$ which were varied $\pm 1{ }^{\circ} \mathrm{C}$ (Kitchell et al. 1977) while holding other parameters constant (including the p-value).

Acoustic measures of bay anchovy abundance. We used acoustics to estimate bay anchovy densities in Chesapeake Bay. The acoustic techniques are detailed in Brandt $(1989,1990,1992)$ and Brandt et al. (1991a, b, 1992) and briefly summarized here. Acoustic data were collected continuously along designated transects using a $120 \mathrm{kHz}$ echosounder having dual-beam transducers, digitally-controlled features (pulse length, pulse repetition rate, etc.), time-varied gain to correct for signal spreading and absorption, and internal calibrations. The transducer was towed near-surface alongside the research vessel. Acoustic data were adjusted for signal spreading and absorption and then fed through a digital audio processor and tape interface to a digital tape recorder. Echo-squared integration and dual-beam analyses of the acoustic data provided measures of acoustic target strength and fish density (Traynor \& Ehrenberg 1979, Burczynski \& Dawson 1984, Burczynski \& Johnson 1986). Fish densities were measured throughout the water column using narrow depth intervals $(0.5 \mathrm{~m})$ and averaged over constant time intervals ( $10 \mathrm{~s}$, ca $25 \mathrm{~m}$ ) that were determined on the basis of observed scattering patterns. Fish lengths were estimated from measured 
target strengths using an equation specific for Clupeids (Foote et al. 1986, Foote 1987). Data were transferred to a workstation for further data processing and imaging using an Multifrequency Acoustic Visualization And Information Retrieval (MAVAIR) System under development at the Chesapeake Biological Laboratory.

Acoustic data were collected during day and night on 3 cross-bay sections at the Calvert Cliffs Nuclear Power Plant, Cove Point and Cedar Point (mid-Chesapeake Bay, Maryland) bimonthly during July, September-October, and November 1989 and January, March-April, May and July 1990. Midwater and bottom trawls were used to identify fish targets and to measure fish size (Brandt 1992).

Spatially-explicit model of consumption. Spatially-explicit models demonstrate how changes in spatial patterning and absolute scaling of the environment (biotic and abiotic) might affect consumption, growth rates and system production (Brandt. et al. 1992). Traditional models of population production are normally based on mean conditions over large areas, and assume homogeneity and constancy of the environment. But, recent work suggests that spatial patchiness of density-dependent and density-independent processes can significantly affect population processes including predator-prey interactions, trophic efficiency, and system-level production (Kareiva \& Andersen 1988, Possingham \& Roughgarden 1990). Fish consumption depends on both the physiology of the species and the constraints imposed by the habitat (such as water temperature) which the fish occupies. Food consumption of a species in a locale is also a function of predator size and predator density. Therefore, the patchy distribution of fish density, size, and water temperature could produce complex spatial patterns of predation pressure on zooplankton which may be very important to the trophic efficiency of the ecosystem (Persson et al. 1992).

We modeled space as an explicit feature of the habitat. The water column was divided into columns (horizontal distance) and rows (water depth) that defined a grid. The grid-based model has a cell (or particular volume of water) as the basic unit. The number and size of the cells were determined by water depth, horizontal extent, and the scale(s) of observation. We simulated the maximum consumption rates of bay anchovy on zooplankton based on acoustic and temperature data collected during day across a $7.5 \mathrm{~km}$ section of the mesohaline portion of the Bay (off Cove Point) during May and July 1990. The simulations were done for data collected during the day since bay anchovy

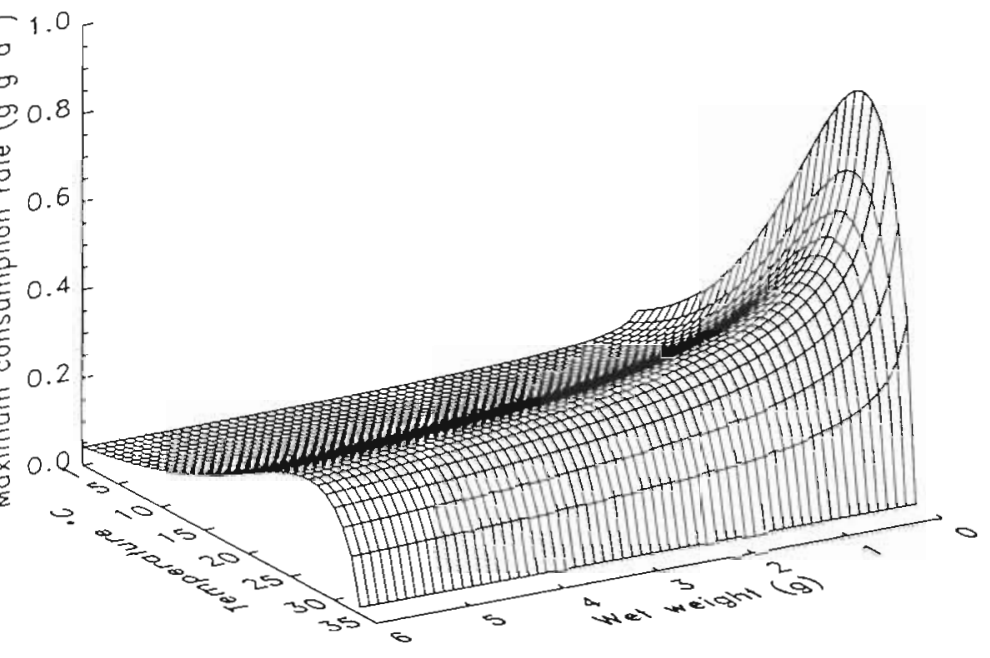

ig. 1. Anchoa mitchilli. Maximum consumption of bay anchovy as a function of temperature $\left({ }^{\circ} \mathrm{C}\right)$ and wet body weight $(\mathrm{g})$

feed mainly during the day in Chesapeake Bay (Klebasko 1991). Consumption rates were simulated in each spatial cell as a function of bay anchovy size $(\mathrm{mm})$, density (ind $\mathrm{m}^{-3}$ ), and water temperature $\left({ }^{\circ} \mathrm{C}\right.$ ) using the bioenergetics consumption model described above. The output of this simulation defines the maximum potential predation pressure on zooplankton by the bay anchovy under the observed environmental conditions in each cell. The integration of consumption rates over all individuals in each cell and over all water volumes produced an estimate of system consumption rate of bay anchovy on zooplankton.

In this study, we focused on bay anchovy consumption and assumed that the numbers of individuals in the population remained constant over the short term. Mortality, recruitment, and immigration/emigration can be added in a straightforward manner. We displayed results of the completed model using recent developments in visualization technology (Brandt et al. 1992) to provide a framework to better understand the spatial relationships of these processes (Platt \& Sathyendranath 1988, Manley \& Tallet 1990).

\section{RESULTS AND DISCUSSION}

\section{Model output}

Energy budget. Maximum consumption $\left(C_{\max }, \mathrm{g} \mathrm{g}^{-1}\right.$ $\mathrm{d}^{-1}$ ) of bay anchovy was a nonlinear function of fish weight and water temperature (Fig. 1). Maximum consumption is the physiological maximum daily ration that determines the ultimate upper bound on the growth potential of a fish (Stewart \& Binkowski 1986). The dependencies of maximum consumption on tem- 


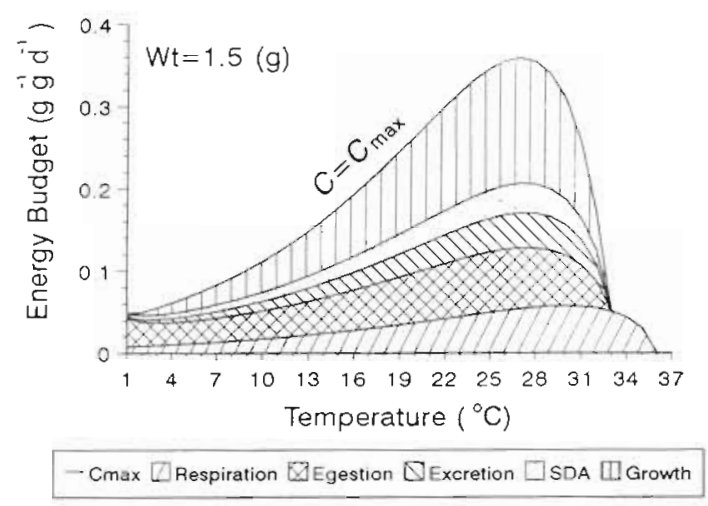

Fig. 2. Anchoa mitchilli. Energy budget of $1.5 \mathrm{~g}$ bay anchovy as a function of temperature

perature and weight is fundamental for understanding the predation dynamics of a predator (Kitchell et al. 1977). We took a cross section of Fig. 1 at the $x$-axis (fish weight) to show the model output of the relationship between temperature and all component rates of the energy budget for a $1.5 \mathrm{~g}$ bay anchovy (Fig. 2). Maximum growth rate occurs at about 26 to $27^{\circ} \mathrm{C}$, and growth stops below $3^{\circ} \mathrm{C}$ and above $32^{\circ} \mathrm{C}$.

Growth. Model output of age-0 bay anchovy body weight and weight-specific growth rates (Fig. 3) as a function of time of year for the 8 cohorts show that during the summer, growth rates of juvenile bay anchovies ranged from 4 to $6 \%$ of body weight $\mathrm{d}^{-1}$ (Fig. 3b) and that the earlier-hatched bay anchovies could exceed a weight of $1 \mathrm{~g}$ (about $50 \mathrm{~mm}$ fork length) before the first winter whereas the latest-hatched fish would only reach about $0.3 \mathrm{~g}$ before their first winter (Fig. 3a). Growth rates were highest in August and September. Model output shows no growth during the winter for all cohorts.

Although the model parameters were estimated from different studies, the results are strongly supported by field observations (Houde et al. 1989, Luo 1991, Zastrow et al. 1991). In mid-Chesapeake Bay, Zastrow et al. (1991) reported that most YOY bay anchovy growth rates ranged from 0.40 to $0.50 \mathrm{~mm} \mathrm{~d}^{-1}$, which were equivalent to 4 to $7 \%$ of growth in body weight $\mathrm{d}^{-1}$. Fives et al. (1986) reported an average growth rate of $0.84 \mathrm{~mm} \mathrm{~d}^{-1}$ (about $9 \%$ ) for 37 to $48 \mathrm{~d}$ old bay anchovy in a North Carolina estuary.

The seasonal trend of relative population biomass of YOY bay anchovy was evaluated by initiating the population sizes of cohorts with the biweekly hatch-date frequency of bay anchovy during the 1987 spawning season (Houde et al. 1989) and by evenly distributing an annual mortality of $95 \%$ (Newberger 1989) over the year, then by summing the biomass of all cohorts (Fig. 3c). The biomass of the bay anchovy population
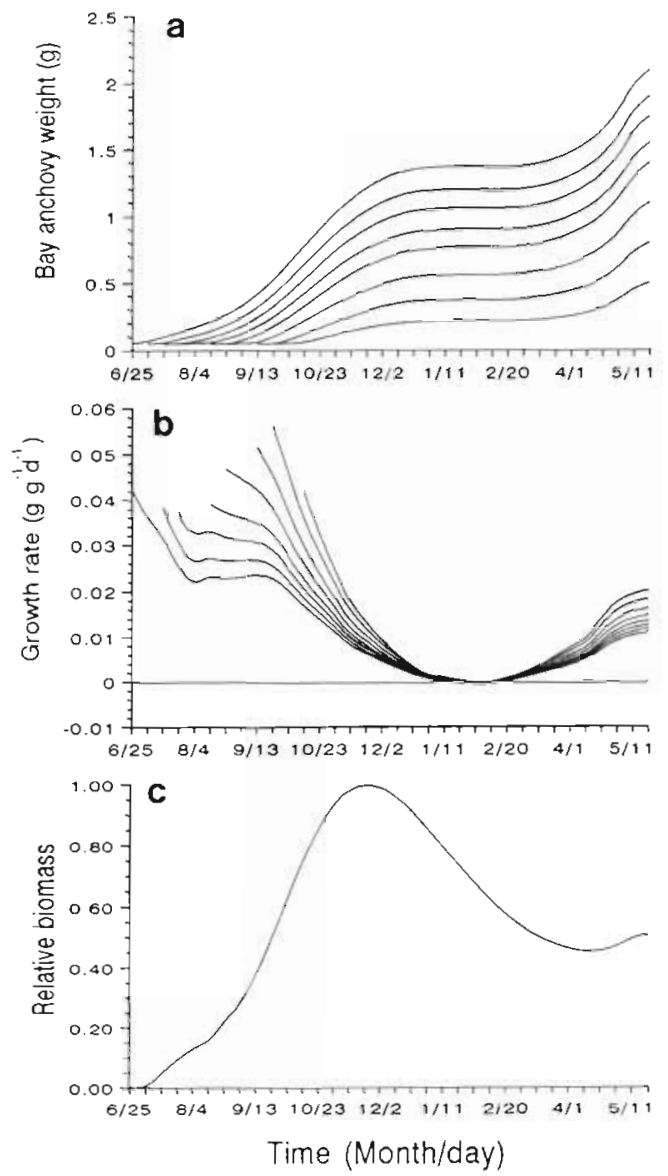

Fig. 3. Anchoa mitchilli. (a) Wet weight of individuals as function of time by cohort. (b) Cohort specific growth rate $\left(\mathrm{g} \mathrm{g}^{-1}\right.$ $\mathrm{d}^{-1}$ ) as a function of time. (c) Model estimate of relative trend of biomass

increased very quickly after August, and reached a peak in November, which closely matches the trawl survey (Horwitz 1987, Luo 1991) and acoustic estimates (Brandt 1992). After November, bay anchovy biomass decreased slowly during the winter and reached a small trough in April before increasing to a secondary peak in May. This differs somewhat from field observations of changes in biomass in Chesapeake Bay (Horwitz 1987, Luo 1991, Brandt 1992), which declines sharply after November and reaches a minimum in January. This discrepancy could be a result of winter emigration of bay anchovy from the Bay which is not yet simulated in our model.

The shape of the population biomass curve would be different if the mortalities were unevenly distributed over the year. Mortality rates for early life stage of bay anchovy are usually very high and also highly variable. Castro \& Cowen (1991) reported that during egg/yolk-sac period the mortalities ranged from 70 to $95 \% \mathrm{~d}^{-1}$, and during the larval period the mortalities ranged from 16 to $38 \% \mathrm{~d}^{-1}$. Mortalities after the larval 

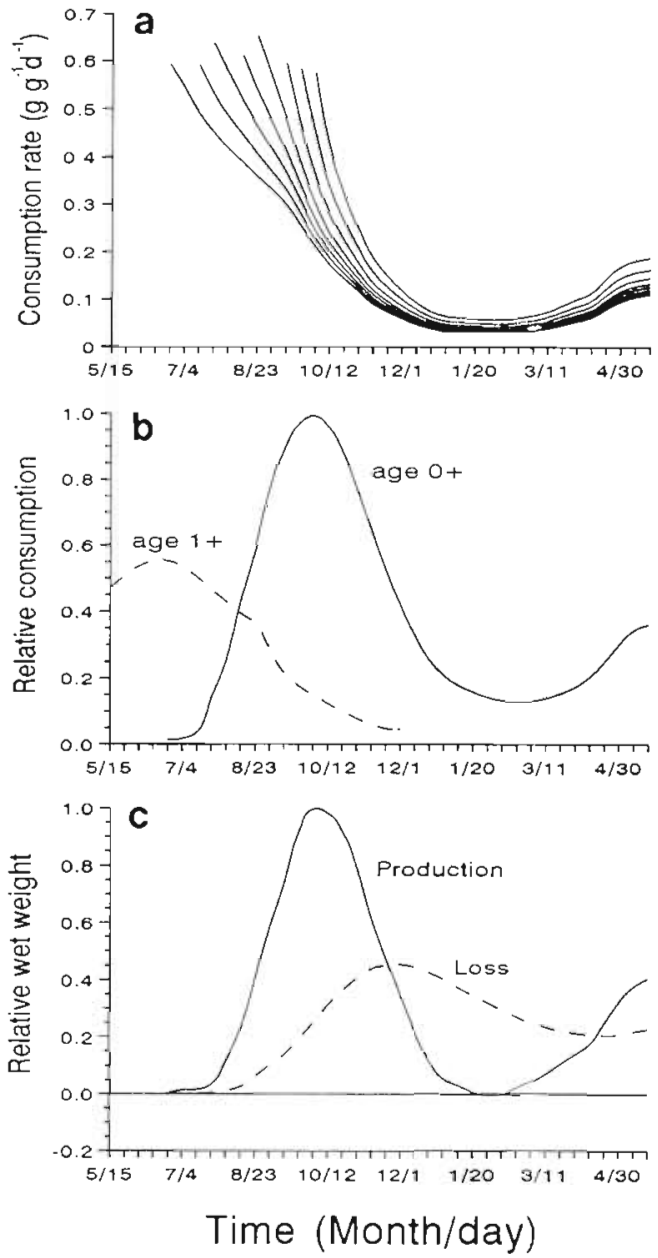

Fig. 4. Anchoa mitchilli. (a) Cohort specific consumption rate $\left(\mathrm{g} \mathrm{g}^{-1} \mathrm{~d}^{-1}\right)$ of YOY bay anchovy as a function of time. (b) Model estimate of relative trend of zooplankton consumed by age $0+$ and age $1+$ bay anchovy. (c) Model estimate of relative daily population production and loss (predation and emigration) of age $0+$ bay anchovy

period are low and relatively stable. Newberger (1989) reported that in mid-Chesapeake Bay the annual mortality rate of post-larval bay anchovy ranged from 89 to $95 \%$. Thus, we started model simulations after the larval stage to avoid the uncertainty of larval mortality.

Consumption. Weight-specific consumption rate of juvenile bay anchovy was about $60 \%$ of body weight during the summer and dropped sharply as bay anchovy grew and water temperatures decreased during the fall (Fig. 4a). Even though the bioenergetics model predicted no growth during winter, bay anchovy still consumed food at about 5 to $8 \%$ body weight $\mathrm{d}^{-1}$ to maintain basic metabolism. Model simulations of growth fitted to final weight indicates that food consumption rates were ranging from 60 to $70 \%$ of maximum possible consumption for all 8 cohorts. This sug- gests that growth of bay anchovy in mid-Chesapeake Bay is weakly food limited (Post 1990), i.e. bay anchovy can grow quite well even under relatively low food density.

The seasonal trend of relative daily population consumption (Fig. $4 \mathrm{~b}$ ) is the sum of consumptions by the 8 cohorts. Daily consumption of zooplankton by YOY bay anchovy peaked at the end of September which matches the usual secondary zooplankton abundance peak in mid-Chesapeake Bay (Olson 1987, Klebasko 1991, White \& Roman 1992).

Production and predation. Daily population production is the sum of weight increment of all individuals in the population and can be related to systemwide production. Our results indicate that daily production of bay anchovy (Fig. 4c) reached a peak at the end of September corresponding to the peak of daily consumption (Fig, 4b). Daily population predation is the total loss of biomass due to predation (assuming other sources of mortalities and emigration are very small) and can be used to link the production of bay anchovy to the production of higher trophic level predators (such as striped bass, bluefish Poatomus satatrix, and weakfish Cynoscion regalis). Simulations indicated that the peak daily predation occurred at the end of November (Fig. 4 bottom panel). Similar to the biomass curve, the shape of the predation curve is also determined by the distribution of mortality. A bioenergetics model of the predators on bay anchovy would result in a different seasonal pattern of mortality than the assumption here of $95 \%$ over the first year.

\section{Sensitivity analyses}

The calculated sensitivities are self-normalized and provide a good measure of the relative sensitivity of simulated yearly fish growth and zooplankton consumption to each parameter (Fig. 5). A sensitivity of $S_{k}= \pm 1.0$ means that a change of parameter $k$ by $10 \%$ causes a resultant $10 \%$ change in annual food consumption or annual growth. Our results indicate that annual growth is more sensitive than food consumption to differences in parameter estimates. For example, a $+10 \%$ change of $P$ increased yearly growth by $144 \%$ (Fig. $5 a$ ), whereas yearly consumption only increased by about $84 \%$ (Fig. 5b).

The proportion of maximum consumption $(P)$, the intercept for maximum consumption $\left(a_{c}\right)$ and standard respiration $\left(a_{\mathrm{r}}\right)$, the activity parameter $(A)$, and the slope for temperature-dependence of consumption and respiration $(Q)$ have the highest overall sensitivities, whereas maximum temperature for consumption and respiration $\left(T_{\mathrm{m}}\right)$, specific dynamic action coefficient $(S)$, and proportion of assimilated food excreted $\left(a_{u}\right)$ have 


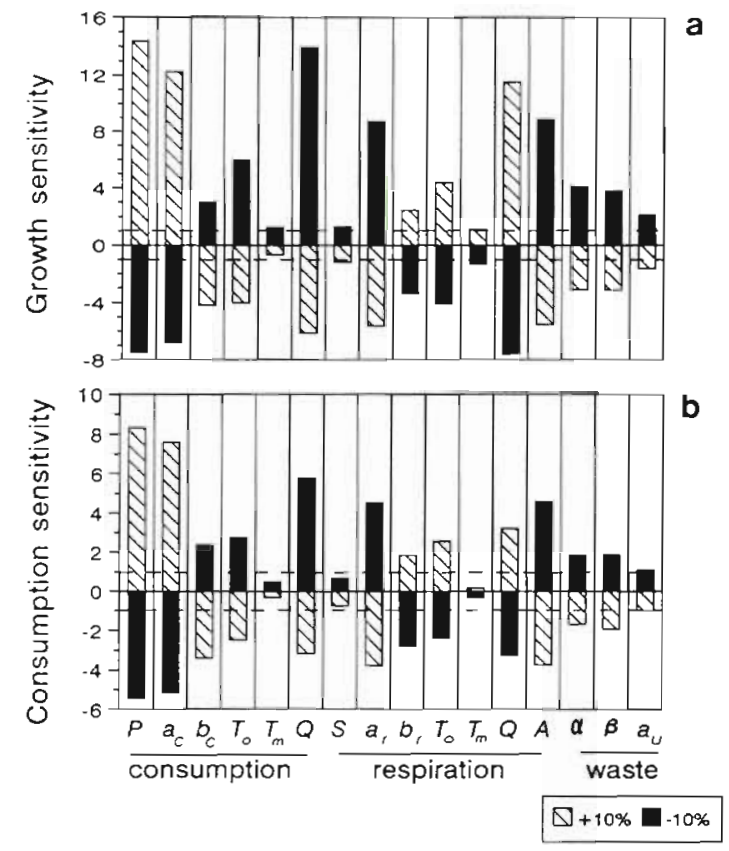

Fig. 5. Normalized sensitivities of (a) growth and (b) consumption to $\pm 10 \%$ changes of each parameter; $P=$ proportion of maxinum consumption; $a_{c}=$ intercept for maximum consumption; $b_{c}=$ slope for maximum consumption; $T_{0}=$ optimum temperature $T_{m}=$ maximum temperature; $Q=$ slope for temperature dependence of consumption and respiration; $S=$ specific dynamic action coefficient $a_{\mathrm{r}}=$ intercept for maximum standard respiration; $b_{\mathrm{r}}=$ slope for maximum standard respiration; $A=$ an activity parameter to specify active respiration; $\alpha=$ intercept for proportion of consumed food egested; $\beta=$ coefficient for egestion vs temperature; $a_{u}=$ proportion of assimilated food excreted

the lowest overall sensitivities. The parameter $P$ is the proportion of maximum food that a bay anchovy actually consumed, and is an indicator of food availability (Post 1990). In our model simulation, $P$ is estimated by fitting growth to the final weight. Therefore, for future improvement of the model, high priority should be given to better estimates of the most sensitive parameters $a_{c}, a_{r}, A$ and $Q$.

In this study, we used stomach contents of fieldcollected samples to estimate the weight-dependence of maximum consumption because the laboratory consumption data from Vazquez (1989) did not provide adequate information on bay anchovy size. Our estimate of the intercept of $C_{\max }$ may be significantly lower than the actual values, but the shape of the weight-dependent function for consumption (i.e. $b_{c}$ ) should not be significantly different. The activity multiplier is a very important component of bioenergetics models, but direct measurements of this parameter are lacking because of the logistic difficulties involved (Boisclair \& Leggett 1989). The estimates of this multi-
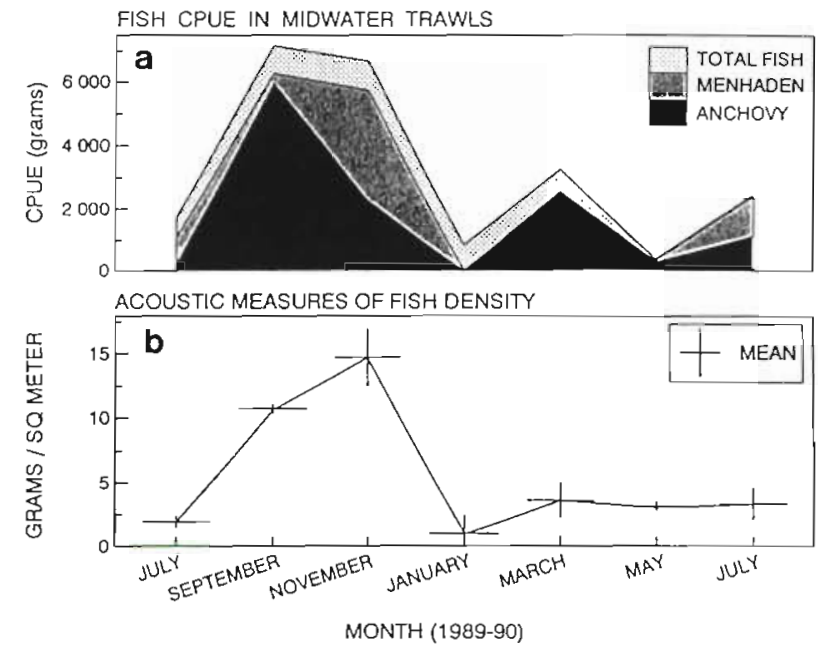

Fig. 6. Comparison of (a) mean catch of fishes in midwater trawls with (b) acoustic measures of fish abundances in mid-Chesapeake Bay

plier ranged wildly from species to species (Brett \& Groves 1979), and even differed between populations (Boisclair \& Leggett 1989). The bay anchovy is an actively swimming fish, presumably with a large activity multiplier value. In this study, we chose $A=2.0$ based on the following information. First, the metabolism rates measured by Vazquez (1989) were from a group of 10 to 14 bay anchovies so that these measurements were most likely higher than the standard metabolism. Second, energy budget in this study is a daily rate. Even though the bay anchovy is very active during the day, the activity of the bay anchovy during the darkness is significant reduced (Luo 1993). Therefore, the activity averaged over a day may be relatively low. The point of the argument is that more experiments are necessary for better estimation of these parameters.

\section{Biomass estimates of bay anchovy}

Overall acoustic estimates of mean fish biomass per unit surface area (Fig. 6b) in mid-Chesapeake Bay showed a distinct peak during fall, a minimum in January, and relatively low constant values during spring and summer. Biomass densities peaked at $10.7 \mathrm{~g}$ $\mathrm{m}^{-2}$ and $14.7 \mathrm{~g} \mathrm{~m}^{-2}$ during September and November, respectively. Biomass densities during March, May and July ranged from 3 to $4 \mathrm{~g} \mathrm{~m}^{-2}$. The seasonal pattern of fish biomass densities closely matched the pattern in overall mean catch of fishes in midwater trawls for all species combined (Fig. 6a). The catch per unit effort (CPUE) in midwater trawls showed a predominance of bay anchovy year round except for November in which Atlantic menhaden Brevoortia tyrannus contributed a significant proportion of the catch by weight. 


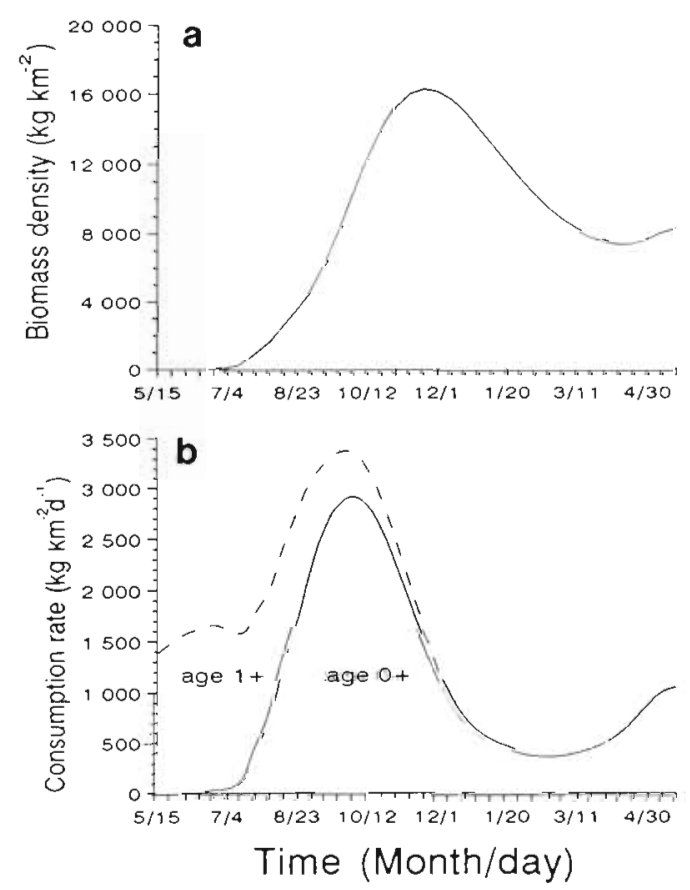

Fig. 7. Anchoa mitchilli. (a) Calibrated age $0+$ bay anchovy biomass density as a function of time. (b) Calibrated food consumption rates by age $0+$ and age $1+$ bay anchovy population

\section{Model outputs calibration}

After reviewing the midwater trawl catch data and the acoustic data, we decided to use the September acoustic biomass density estimate to calibrate the output of model simulations because September acoustic data had the smallest variation among all the other months and September midwater trawl catches showed that $95 \%$ of the pelagic fishes were bay anchovy. By adjusting acoustic estimates of total fish abundance by the proportion of those fish estimated to be bay anchovy from trawl catches, we estimated that the bay anchovy biomass density at the end of September was $10165 \mathrm{~kg} \mathrm{~km}^{-2}$ $\left(10700 \mathrm{~kg} \mathrm{~km} \mathrm{~km}^{-2} \times 0.95\right)$. This estimate was then used to calibrate the model output of population biomass, consumption, production, and loss (predation and emigration).

The peak biomass density of YOY bay anchovy was estimated at $16273 \mathrm{~kg} \mathrm{~km}^{-2}$ and occurred in November (Fig. 7a). The peak of consumption rate was $2915 \mathrm{~kg}$ $\mathrm{km}^{-2} \mathrm{~d}^{-1}$ by YOY bay anchovy and was $3353 \mathrm{~kg} \mathrm{~km}^{-2}$ $\mathrm{d}^{-1}$ when combined with age $1+$ year class (Fig. 7b), and both occurred in September. The mean consumption rate of YOY bay anchovy was $1114 \mathrm{~kg} \mathrm{~km}^{-2} \mathrm{~d}^{-1}$ and the annual consumption was $378630 \mathrm{~kg} \mathrm{~km}^{-2}$ which was estimated by integrating the area under the age $0+$ curve.
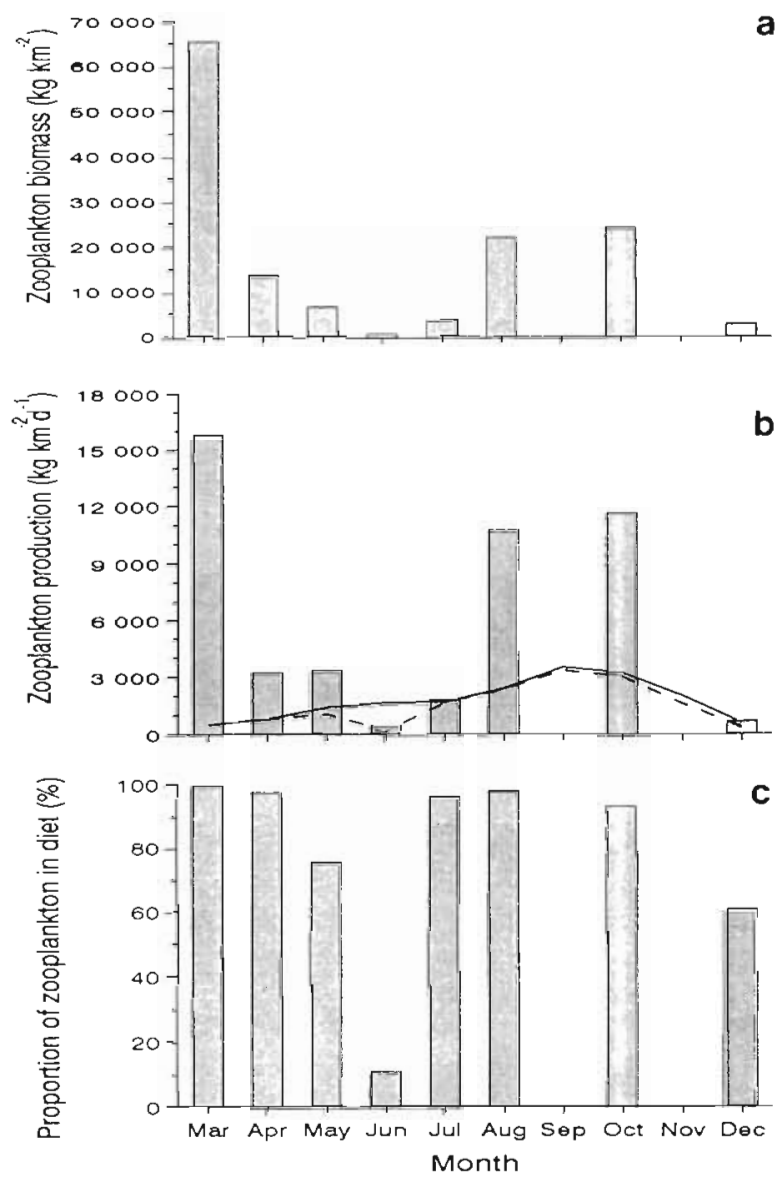

Fig. 8. (a) Seasonal distribution of zooplankton biomass in mid-Chesapeake Bay. (b) Zooplankton production (bars); total bay anchovy consumption (solid line); bay anchovy consumption on zooplankton (dashed line). (c) Proportion of zooplankton in bay anchovy stomach. (Data were recalculated from Klebasko 1991)

The model output of consumption was compared with the ambient zooplankton biomass of 1990 in midChesapeake Bay (Fig. 8a; data from Klebasko 1991), production (Fig. 8b), and bay anchovy diet composition (Fig. $8 \mathrm{c}$ ). We used an average production rate of $48 \%$ of biomass (Heinle 1966) to estimate zooplankton production during summer and fall (May to October) and used half of that rate (24\%) to estimate zooplankton production in other months. During the high bay anchovy consumption period (August to October), the total consumption (Fig. 8b, solid line) was about 1/3 of zooplankton production. In June, even though bay anchovy consumption demand is relatively low, it exceeded the zooplankton production by 3 -fold. To compensate for this shortage of zooplankton, bay anchovy were apparently able to switch over to feed predominantly (89\%; Fig. 8c) on other prey (such as barnacle cyprids, amphipods, and other benthic crustaceans; data from Klebasko 1991). The bay anchovy is known 

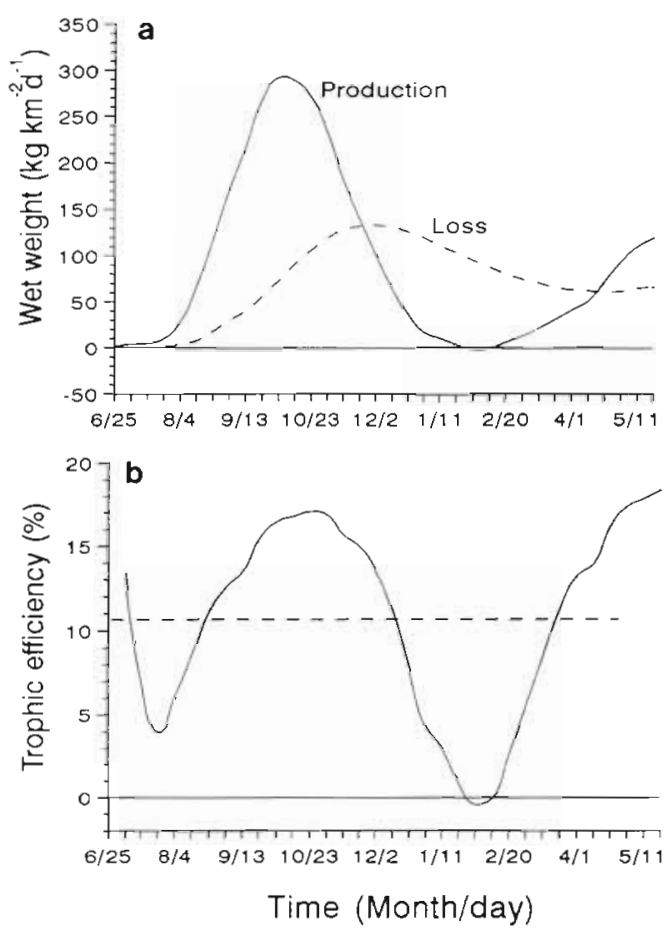

Fig. 9. Anchova mitchilli. (a) Calibrated population production rates and predation loss of YOY bay anchovy. (b) Trophic efficiency of bay anchovy as a function of time

for rapidly switching prey types according to food availability (Johnson et al. 1990). Bay anchovy consumption on zooplankton (dashed line, Fig. 8b) was estimated by multiplying the total consumption with the proportion of zooplankton found in bay anchovy stomachs (Fig. 8c).

The low zooplankton production of June can be explained by bottom-up controlling processes. The spring bloom, which supplies food for zooplankton, collapses as nutrients (such as silicate, phosphorous, and nitrogen) are depleted in mesohaline waters of Chesapeake Bay (Sellner \& Kachur 1987, Conley \& Malone 1992). This subsequently leads to the collapse of zooplankton. But this bottom-up controlling process may not go beyond higher trophic levels because bay anchovy are able to consume alternative food sources (i.e. benthic prey).

The peak population production rate of YOY bay anchovy also occurred in September and was $290 \mathrm{~kg} \mathrm{~km}^{-2}$ $\mathrm{d}^{-1}$ (Fig. 9a), and the annual production was $30770 \mathrm{~kg}$ $\mathrm{km}^{-2}$ with a mean of $90 \mathrm{~kg} \mathrm{~km}^{-2} \mathrm{~d}^{-1}$. The loss of bay anchovy biomass (predation and emigration) peaked at the same time as the biomass density with a value of $133 \mathrm{~kg} \mathrm{~km} \mathrm{~km}^{-2} \mathrm{~d}^{-1}$, which could supply food for about 13300 age -2 striped bass $\mathrm{km}^{-2}$ under maximum daily consumption ( $500 \mathrm{~g}$ striped bass feeds at a rate of about $2 \%$ body weight $\mathrm{d}^{-2}$ ) if we assumed that all the loss was due to predation. The annual predation loss was estimated at $23700 \mathrm{~kg} \mathrm{~km}^{-2}$ with a mean of $70 \mathrm{~kg} \mathrm{~km}^{-2} \mathrm{~d}^{-1}$.

In our model simulation, we assumed that mortalities are evenly distributed over the year. It is clear that this assumption is unrealistic, but at the present time there is not enough data to produce a realistic mortality curve. The next step of study is to model the mortality as a nonlinear function of predator abundances and environmental conditions.

The trophic efficiency (Baird \& Ulanowicz 1989) or the ecological efficiency (Levinton 1982) was calculated as the ratio of population production rate (cal $\mathrm{d}^{-1}$ ) to population consumption rate $\left(\mathrm{cal} \mathrm{d}^{-1}\right)$, and had large seasonal variations ranging from around $0 \%$ in winter to above $15 \%$ in spring and fall (Fig. 9b). The annual average trophic efficiency was $10.7 \%$ which is coincidentally very close to the theoretical expectation of $10 \%$ (Ryther 1969, Slobodkin 1970, Baird \& Ulanowicz 1989).

\section{Spatial patterns of bay anchovy consumption}

Our results showed quite different distribution patterns of predation pressure on zooplankton between May and July (Figs. 10 \& 11). During May, the predation pressure was rather evenly distributed across the Bay and throughout the entire water column with a few small patches of high predation in shallow regions of the Bay. During July, the distribution of predation pressure was much patchier than that during May; high predation occurred in a large portion of the shallow region of the western shore, and moderate predation occurred only above the pycnocline because hypoxia below the pycnocline excluded bay anchovy from these areas. The integration of the predation potential over all volumes provided an estimate of system-level consumption by bay anchovy. The average consumption for July (1746 $\mathrm{kg} \mathrm{km}^{-2} \mathrm{~d}^{-1}$ ) exceeded that for May $\left(1127 \mathrm{~kg} \mathrm{~km}^{-2} \mathrm{~d}^{-1}\right.$ ) even though the overall mean bay anchovy biomass density for July $(0.222 \mathrm{~g}$ $\left.\mathrm{m}^{-3}\right)$ was similar to that for May $\left(0.225 \mathrm{~g} \mathrm{~m}^{-3}\right)$, because consumption rate is a nonlinear function of fish size and water temperature. These estimates of consumption rates are close to the population consumption rates estimated by a different method presented above (Fig. 7b). We used the volumetric distribution of predation pressure to define the proportion of the Bay volume that will contain various levels of predation on zooplankton by bay anchovy. During May, $30 \%$ of the water volume was characterized by no consumption and $4 \%$ of water volume had consumption rates higher than $0.1 \mathrm{~g} \mathrm{~m}^{-3} \mathrm{~d}^{-1}$ (Fig. 12a). In contrast, during July, $65 \%$ of the water volume had no consumption and $13 \%$ of the water volume had consumption rates higher than $0.1 \mathrm{~g} \mathrm{~m}^{-3} \mathrm{~d}^{-1}$ (Fig. 12b). 

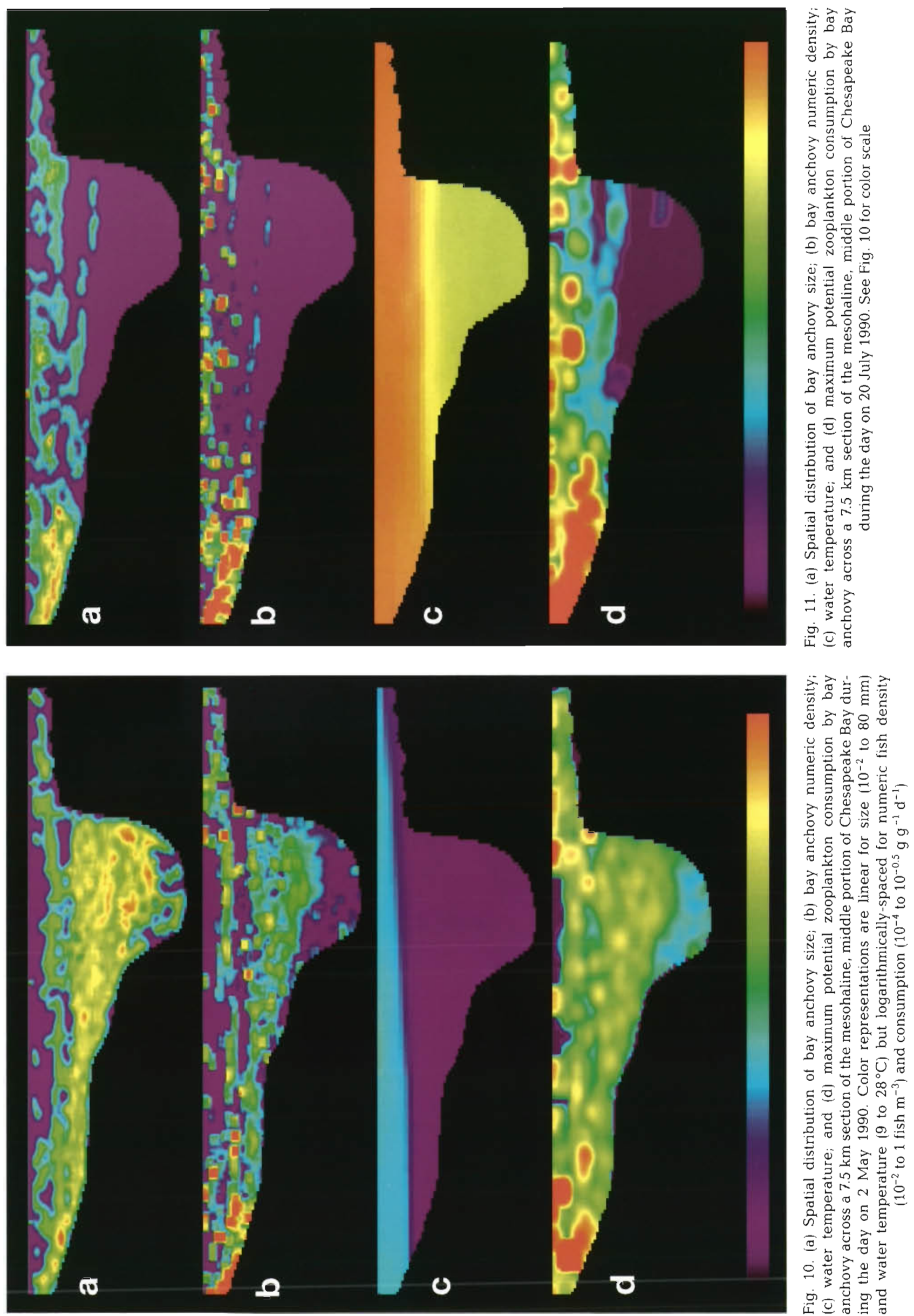


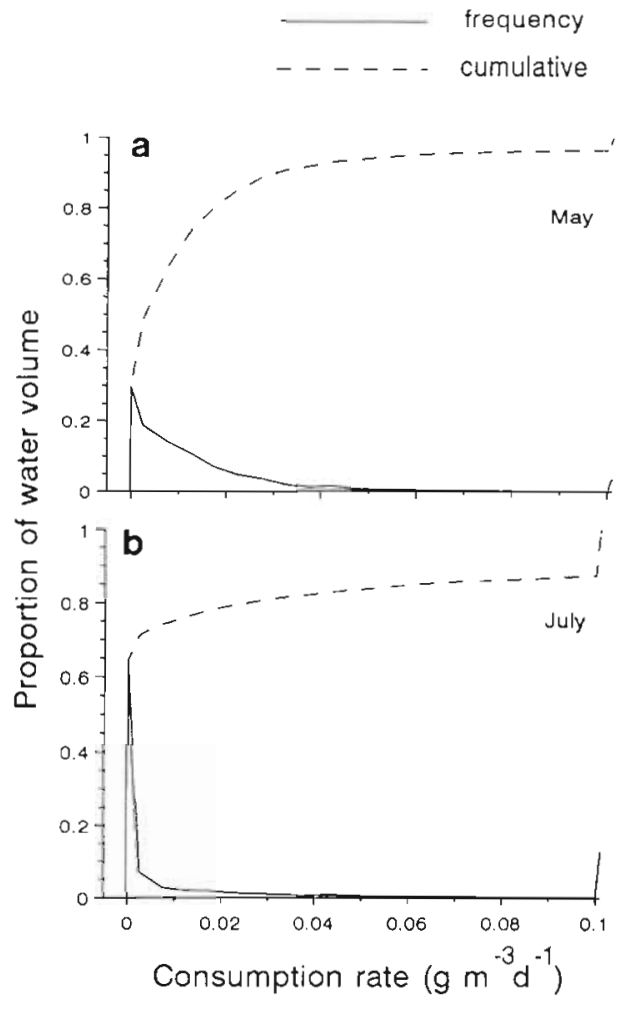

Fig. 12. Volumetric frequency distribution of zooplankton consumption by bay anchovy during (a) May and (b) July 1990

\section{CONCLUSIONS}

Bioenergetics and population models can now be used to link zooplankton production to bay anchovy consumption. The interaction between bay anchovy and zooplankton and other species may be modified by the bottom-up forces (water quality and nutrient dynamics) and the top-down forces (piscivores; such as bluefish, striped bass and weakfish) in the Bay system (Carpenter et al. 1985, 1987, Scavia et al. 1986, Crowder et al. 1987, Carpenter \& Kitchell 1988, Verity 1988, Lee \& Jones 1991, Hunter \& Price 1992, Power 1992, Strong 1992).

In mid-Chesapeake Bay, the peak daily population consumption by bay anchovy corresponds to the secondary peak of zooplankton production in fall, and consumption only accounts for a small portion of daily zooplankton production throughout the year except in June and July, when bay anchovy are able to feed on alternative prey (Fig. 8). These results suggest that at the present level of bay anchovy abundance, the predation pressure on zooplankton is not high enough to significantly deplete systemwide production of zooplankton in mid-Chesapeake Bay, and also indicate that bay anchovy population in mid-Chesapeake Bay may not be limited by their food resource, although local depletions are possible due to spatial patchiness of predator and habitat heterogeneity. Therefore, it can be argued that large reductions in nutrient loading, which will reduce the production of phytoplankton and zooplankton, may not have as large an impact on the production of bay anchovy and ultimate production of piscivores in midChesapeake Bay, i.e. bottom-up influences on the ecosystem are buffered by bay anchovy populations.

Simulations and acoustic measurements indicate that the bay anchovy biomass and consequently the food resource of the piscivores (assume 95\% annual mortality) peak in November (Fig. 9a), and that anchovy production could support the consumption of 13300 age- 2 striped bass $\mathrm{km}^{-2}$ if we do not consider competition with other piscivores. The top-down trophic cascades may also be buffered by the bay anchovy populations because of the weak relationship between zooplankton production and bay anchovy consumption, and bay anchovy's ability to feed on alternative prey.

The Chesapeake Bay estuary is a dynamic ecosystem. Changes in interactions between trophic levels and among species of the same trophic level can be expected. Single-species models can be considered good starting points of whole-system models. In the future, models should allow real time interactions within appropriate spatial scales among any combinations or all of the following sub-models: water quality models, plankton and benthos models, submerged aquatic vegetation models, emergent inertial wetland models, and fish bioenergetics models.

Acknowledgements. This research was funded by the National Science Foundation, Biological Oceanography Program (OCE-9116071), EPA Grant (92-085), the Maryland Department of Natural Resources (PR9-114-004, CB91-008004), Maryland Sea Grant Program (NA90AA-D-SG063 R/F65). New York Sea Grant Institute (228-SO15P), Electric Power Research Institute (SFI/EPRI-09-07), and the Sport Fishing Institute (SERP-90-21). We thank Drs E. Houde, $J$. Cowan, and 3 anonymous reviewers for critical reviews of the manuscript; J. Kitsch, D. Mason, E. V. Patrick for help with the processing of acoustic data and image presentation; $J$. Cowan and $K$. Rose for sharing the information of their bay anchovy model; $M$. Klebasko for providing bay anchovy stomach content data; and the crew of the RV 'Orion' and the multitude of scientific personnel for help at sea.

\section{LITERATURE CITED}

Baird, D., Ulanowicz, D. E. (1989). The seasonal dynamics of the Chesapeake Bay ecosystem. Ecol. Monogr. 59: 329-364

Bartell, S. M., Breck, J. E., Gardner, R. H., Brenkert, A. L. (1986). Individual parameter perturbation and error analysis of fish bioenergetics models. Can. J. Fish. Aquat. Sci. 43: 160-168

Beauchamp, D. A., Stewart, D. J., Thomas, G. L. (1989). Corroboration of a bioenergetics model for sockeye salmon. Trans. Am. Fish. Soc. 118: 597-607 
Bevelheimer, M. S., Stein, R. A., Carline, R. F. (1985). Assessing significance of physiological differences among three esocids with a bioenergetics model. Can. J. Fish. Aquat Sci. 42: 57-69

Boisclair, D., Leggett, W. C. (1989). The importance of activity in bioenergetics models applied to actively foraging fishes. Can. J. Fish. Aquat. Sci. 46: 1859-1867

Brandt, S. B. (1989). Hydroacoustics as a stock assessment technique in the Potomac River. Final Report. (Contract No. F-135-88-008) to the Maryland Department of Natural Resources, [UMCEES]CBL 89-094, Annapolis

Brandt, S. B. (1990). Acoustic quantification of fish abundance in the Chesapeake Bay. Progress Report to Maryland Department of Natural Resources, Power Plant Topical Research Program, [UMCEES]CBL 90-047, Annapolis

Brandt, S. B. (1992). Acoustic measurement of fish abundance in the Chesapeake Bay. Final Report to Maryland Department of Natural Resources, Power Plant Topical Research Program, [UMCEES]CBL 92-054, Annapolis

Brandt, S. B., Mason, D. M., Patrick, E. V. (1992). Spatiallyexplicit models of fish growth rate. Fisheries (Bull. Am. Fish. Soc.) 17(2): 23-33

Brandt, S. B., Mason, D. M., Patrick, E. V., Argyle, R. L., Wells, L., Unger, P. A., Stewart, D. J. (1991a). Acoustic measures of the abundance and size of pelagic planktivores in Lake Michigan. Can. J. Fish. Aquat. Sci. 48: 894-908

Brandt, S. B., Patrick, E. V., Mason, D. M., Hartman, K. J. Klebasko, M. J. (1991b). Bioacoustics and bioenergetics: trophic supply and demand in the Chesapeake Bay. In Mihursky, J. (ed.) New perspectives in the Chesapeake Bay system: a science-management partnership. CRC Publication No. 137, Solomons, MD, p. 105-119

Brett, J. R., Groves, T . D. D. (1979). Physiological energetics In: Hoar, W. S., Randall, J. (ed.) Fish physiology, Vol. VIII. Bioenergetics and growth. Academic Press, New York. p. $279-352$

Burczynski, J. J., Dawson, J. (1984). Dual-beam techniques for fish sizing and quantity estimates. BioSonics Applications Memo No. 104

Burczynski, J. J., Johnson, R. L. (1986). Application of dualbeam acoustic survey techniques to limnetic populations of juvenile sockeye salmon (Oncorhynchus nerka). Can. J. Fish. Aquat. Sci. 43: 1776-1788

Carpenter, S. R., Kitchell, J. F., Hodgson, J. R. (1985). Cascading trophic interactions and lake productivity. BioSci. 35 $634-63$

Carpenter, S. R., Kitchell, J. F., Hodgson, J. R., Cochran, P. A., Elser, J. J., Elser, M. M., Lodge, D. M., Kretchmer, D., He, $\mathrm{X}$, von Ende, C. N. (1987). Regulations of lake primary production by food-web structure. Ecology 68: 1863-1876

Carpenter, S. R., Kitchell, J. F. (1988). Consumer control of lake productivity: large-scale experimental manipulations reveal complex interactions among lake organisms. BioSci. 38: 764-769

Castro, L. R., Cowen, R. K. (1991). Environmental factors affecting the early life history of bay anchovy Anchoa mitchilli in Great South Bay, New York. Mar Ecol. Prog. Ser. 76: 235-247

Chao, L. N., Musick, J. A. (1977). Life history, feeding habits, and functional morphology of juvenile sciaenid fishes in the York River estuary, Virginia. Fish. Bull. U.S. 75: 657-702

Conley, D. J. Malone, T C. (1992). Annual cycle of dissolved silicate in Chesapeake Bay: implications for the production and fate of phytoplankton biomass. Mar. Ecol. Prog. Ser. 81: $121-128$
Crowder, L. B., McDonal, M. E., Rice, J. A. (1987). Understanding recruitment of Lake Michigan fishes: the importance of size-based interactions between fish and zooplankton. Can. J. Fish. Aquat. Sci. 44 (Suppl. 2): 141-147

Elliott, J. M., Persson, L. (1978). The estimation of daily rates of food consumption for fish. J. Anim. Ecol. 47 $977-993$

Fives, J. M., Warlen, S. M., Hoss, D. E. (1986). Age and growth of larval bay anchovy, Anchoa mitchilli, from the Newport River estuary, North Carolina. Estuaries 9: 362-367

Foote, K. G., Aglen, A., Nakken, O. (1986). Measure of fish target strength with a split-beam echo sounder. J. Acoust. Soc. Am. 80: 612-621

Foote, K. G. (1987). Fish target strengths for use in echo integration surveys. J. Acoust. Soc. Am. 82: 981-987

Heinle, D. R. (1966). Production of a calanoid copepod Acartia tonsa, in the Patuxent River estuary. Chesapeake Sci. 7: 59-74

Hewett, S. W. (1989). Ecological applications of bioenergetics models. Am. Fish. Soc. Symp. 6: 113-120

Hewett, S. W., Johnson, B. J. (1987). A generalized bioenergetics model of fish growth for microcomputers. University of Wisconsin, Wisconsin Sea Grant College Program, Sea Grant Tech. Rept. WIS-SG-87-245, Madison

Hewett, S. W., Johnson, B. J. (1989). A general bioenergetics model for fishes. Am. Fish. Soc. Symp. 6: 206-208

Hewett, S. W., Johnson, B. J. (1992). An upgrade of a generalized bioenergetics model of fish growth for microcomputers. University of Wisconsin, Wisconsin Sea Grant College Program, Sea Grant Tech. Rept. WIS-SG-92-250, Madison

Hewett, S. W., Stewart, D. J. (1989). Zooplanktivory by alewife in Lake Michigan: ontogenetic, seasonal, and historical patterns. Trans. Am. Fish. Soc. 118: 581-596

Hildebrand, S. F., Schroeder, W. C. (1928). Fishes of Chesapeake Bay. U.S. Bur. Fish. Bull. 43

Hildebrand, S. F. (1943). A review of the American anchovies (Family Engraulidae). Bull. Bingham Oceanogr. Coll. 8(2): $1-165$

Hildebrand, S. F. (1963). Family Engraulidae. In: Olsen, Y H (ed.) Fishes of the Western North Atlantic. Sears Foundation for Marine Research Memoir 1(3). Yale University, New Haven, p. 152-249

Hill, D. K., Magnuson, J. J. (1990). Potential effects of climate warming on the growth and prey consumption of Great Lakes fishes. Trans. Am. Fish. Soc. 119: 265-275

Hollis, E. H. (1952). Variations in the feeding habits of the striped bass, Roccus saxatilis (Walbaum), in Chesapeake Bay. Bull. Bingham Oceanogr. Coll. 14: 111-131

Homer, M., Boynton, W. (1978). Stomach analysis of fish collected in the Calvert Cliffs region, Chesapeake Bay. Chesapeake Biol Lab. Solomons, MD. Ref. No (UMCEES) CBL 78-154

Horwitz, R. J. (1987). Fish. In: Heck, K. L. (ed.) Ecological studies in the middle reach of Chesapeake Bay. Lecture Notes on Coastal and Estuarine Studies 23, SpringerVerlag, Berlin, p. 167-224

Houde, E. D., Chesney, E. J., Newberger, T. A., Vazquez, A. V. Zastrow, C. E., Morin, L. G., Harvey, H. R., Gooch, J. W (1989). Population biology of bay anchovy in Mid-Chesapeake Bay. Ref. No. (UMCEES) CBL 89-141. Chesapeake Biol. Lab., Solomons, MD

Houde, E. D., Zastrow, C. E. (1991). Bay anchovy, Anchoa mitchilli. In: Funderburk, S. L., Mihursky, J. A, Jordan S. J., Riley, D. (eds.) Habitat requirements for Chesapeake Bay living resources, 2nd edn. Living Resources Subcommittee, Chesapeake Bay Program. Annapolis, p. $8.1-8.14$ 
Hunter, M. D., Price, P. W. (1992). Playing chutes and ladders: heterogeneity and the relative roles of bottom-up and topdown forces in natural communities. Ecology 73: 724-732

Johnson, W. S., Allen, D. M., Ogburn, M. V., Stancyk, S. E. (1990). Short-term predation responses of adult bay anchovies Anchoa mitchilli to estuarine zooplankton availability. Mar. Ecol. Prog. Ser. 64: 55-68

Kareiva, P., Andersen, M. (1988). Spatial aspects of species interactions: the wedding of models and experiments. In: Hastings, A. (ed.) Community ecology, Springer-Verlag, New York, p. 38-54

Kitchell, J. F., Stewart, D. J., Weininger, D. (1977). Applications of a bioenergetics model to yellow perch (Perca flavescens) and walleye (Stizostedion vitreum vitreum). J. Fish. Res. Bd Can. 34: 1922-1935

Kitchell, J. F., Breck, J. E. (1980). Bioenergetics model and foraging hypothesis for sea lamprey (Petromyzon marinus). Can. J. Fish. Aquat. Sci. 37: 2159-2168

Klebasko, M. J. (1991). Feeding ecology and daily ration of bay anchovy (Anchoa mitchilli) in the Mid-Chesapeake Bay. M.Sc. thesis, University of Maryland, College Park

Lee, G. F., Jones, R. A. (1991). Effects of eutrophication on fisheries. Rev. Aquat. Sci. 5: 287-305

Levinton, J. S. (1982). Marine ecology. Prentice-Hall Inc., Englewood Cliffs

Luo, J. (1991). Life history of the bay anchovy, Anchoa mitchilli, in Chesapeake Bay. Ph.D. dissertation, College of William and Mary, Williamsburg

Luo, J. (1993). Tidal transport of the bay anchovy, Anchoa mitchilli, in darkness. J. Fish Biol. 42: 531-539

Luo, J., Musick, J. A. (1991). Reproductive biology of the bay anchovy in Chesapeake Bay. Trans. Am. Fish. Soc. 120: $701-710$

Manley, T. O., Tallet, J. A. (1990). Volumetric visualization: an effective use of GIS technology in the field of oceanography. Oceanography 3: 23-29

Merriner, J. V. (1975). Food habits of the weakfish, Cynoscion regalis, in North Carolina waters. Chesapeake Sci. 16: $74-76$

Newberger, T. A. (1989). Relative abundance, age, growth and mortality of bay anchovy in the Mid-Chesapeake Bay. M.Sc, thesis, University of Maryland, College Park

Olson, M. M. (1987). Zooplankton. In: Heck, K. L. (ed.) Ecological studies in the middle reach of Chesapeake Bay Lecture notes on coastal and estuarine studies, Vol. 23 Springer-Verlag, New York, p. 38-81

Persson, L., Deihl, S., Johansson, L., Andersson, G., Hamrin, S. F. (1992). Trophic interactions in temperate lake ecosystems: a test of food chain theory. Am. Nat. 140: 59-84

Platt, T., Sathyendranath, S. (1988). Oceanic primary production: estimation by remote sensing at local and regional scales. Science 241.1613-1620

Possingham, H. P., Roughgarden, J. (1990). Spatial population dynamics of a marine organism with a complex life cycle. Ecology 71: $973-985$

Post, J. R. (1990). Metabolic allometry of larval and juvenile yellow perch (Perca flavescens): in situ estimates and bioenergetic models. Can. J. Fish. Aquat. Sci. 47: 554-560

Power, M. E. (1992). Top-down and bottom-up forces in food

This article was presented by J. E. Purcell, Cambridge Maryland, USA webs: do plants have primacy? Ecology 73: 733-746

Rice, J. A., Cochran, P. A. (1984). Independent evaluation of a bioenergetics model for largemouth bass. Ecology 65 : $732-739$

Ritchie, D. E. Jr, Genys, J. B. (1975). Daily temperature and salinity of surface water of Patuxent River at Solomons, Maryland, based on 30 years of records (1938-1967). Chesapeake Sci. 16: 127-133

Ryther, J. H. (1969). Photosynthesis and fish production in the sea. Science 166: $72-76$

Safina, C., Burger, J. (1989). Common tern foraging: seasonal trends in prey fish densities and competition with bluefish Ecology 66: 1457-1463

Scavia, D., Fahnenstiel, G. L., Evans, M. S., Jude, D. J., Lehman, J. T (1986). Influence of salmonine predation and weather on long-term water quality trends in Lake Michigan. Can. J. Fish. Aquat. Sci. 43: 435-443

Sellner, K. G., Kachur, M. E. (1987). Phytoplankton: relationships between phytoplankton, nutrients, oxygen flux and secondary producers. In: Heck, K. L. (ed.) Ecological studies in the middle reach of Chesapeake Bay. Lecture notes on coastal and estuarine studies, Vol. 23. SpringerVerlag, New York, p. 12-37

Slobodkin, L. B. (1970). Summary. In: Steele, J. H. (ed.) Marine food chains. University of California Press Berkeley, p. 537-540

Stewart, D. J., Weininger, D., Rottiers, D. V., Edsall, T. A (1983). An energetics model for lake trout, (Salvelinus namaycush): application to the Lake Michigan population. Can. J. Fish. Aquat. Sci. 40: 681-698

Stewart, D. J., Binkowski, F. (1986). Dynamics of consumption and food conversion by Lake Michigan alewives: an energetics-modeling synthesis. Trans. Am. Fish. Soc. 115 $643-661$

Stewart, D. J., Ibarra, M. (1991). Predation and production by salmonine fishes in Lake Michigan. Can. J. Fish. Aquat. Sci. 48: 909-922

Strong, D. R. (1992). Are trophic cascades all wet? Differentiation and donor-control in speciose ecosystems. Ecology 73 $747-754$

Traynor, J. J., Ehrenberg, J. E. (1979). Evaluation of the dualbeam acoustic fish target strength measurement method J. Fish. Res. Bd Can. 36: 1065-1071

Vazquez, A. V. (1989). Energetics, trophic relationships and chemical composition of bay anchovy, Anchoa mitchilli, in the Chesapeake Bay. M.Sc. thesis, University of Maryland, College Park

Verity, P. G. (1988). The trophic structure of pelagic communities: hypotheses and problems. In: Lynch, M. P., Krome, E. C. (eds.) Understanding the estuary: advances in Chesapeake Bay research, Ches. Res. Consort. Publ. 129, CBP/TRS 24/88, p. 49-54

White, J. R., Roman, M. R. (1992). Seasonal study of grazing by metazoan zooplankton in the mesohaline Chesapeake Bay. Mar. Ecol. Prog. Ser. 86: 251-261

Zastrow, C. E., Houde, E. D., Morin, L. G. (1991). Spawning, fecundity, hatch-date frequency and young-of-theyear growth of bay anchovy Anchoa mitchilli in midChesapeake Bay. Mar. Ecol. Prog. Ser. 73: 161-171

Manuscript first received: December 11. 1992

Revised version accepted: May 21, 1993 